\title{
海洋天然物ビセリングビアサイド類の作用機序研究 カルシウムポンプを標的とするシアノバクテリア由来のマクロリド
}

生物由来の有機化合物（天然物）は，古くから医薬品 や研究試薬として重宝されてきた。低分子医薬品のおよ そ6割に天然物の炭素骨格が使われている事実からもう かがえるように(1)，ユニークな化学構造と強い生物活性 は天然物の大きな魅力である。しかし，その多くは細胞 や個体に対する生物活性を指標に分離精製されており， 「特定の分子がなぜ生物活性を示すのか」一すなわち作 用機序については，単離された時点では不明の場合がほ とんどである。一方，生命科学研究では分子・原子レ心゙ ルでの生命現象の理解が進み, 創薬研究では分子標的薬 が主流となって久しい．こうした背景から，生物活性物 質を創薬シードや研究ツールとして活かすためには，作 用機序の分子レベルでの理解が不可欠となっている。し かし，天然物の標的分子はタンパク質や核酸，脂質など 多岐にわたるうえに，標的同定の常法がないこともあ り，成功例はいまだ限られている。本稿では，最近の一 例として, 筆者らが行った海洋天然物ビセリングビアサ イド類の作用機序研究を取り上げ, 経緯と展望を交えて 紹介したい。

ビセリングビアサイド類は，沖縄県および鹿児島県に 生息する海洋シアノバクテリアLyngbya属から単離さ れたマクロリド系化合物である（図1A)。2009年に初 めてこの炭素骨格のマクロリドが発見されて以来 ${ }^{(2)}$ ，筆 者らは種々の活性試験を行ってきた。たとえば，ヒトが ん細胞に対する増殖抑制活性やアポトーシス（細胞死） の誘導 ${ }^{(3)}$, 破骨細胞に対する分化抑制活性 ${ }^{(4)}$ などを報告 したが，標的分子は不明であった，冒頭で述べたよう に，標的同定の難しさは新規な生物活性物質の多くに共 通した問題であり，ケミカルバイオロジー分野ではさま ざまな手法が研究されている，筆者らは，がん研究会が ん化学療法センターが構築した 39 株のヒトがん細胞パ ネル (JFCR39) ${ }^{(5)}$ を利用して標的を推定し，それを基に in vitroの阻害活性試験を行った。その結果，ビセリン グビアサイド類は小胞体カルシウムポンプ (sarco/endoplasmic reticulum $\mathrm{Ca}^{2+}$-ATPases; SERCA）の強力な 阻害剤であることが明らかになった（阻害定数 $K_{\mathrm{i}}$ 〜 $10 \mathrm{nM})^{(6)}$ (図 1B).

SERCA は, ATPの加水分解エネルギーを利用して細
胞質側から内腔側へ $\mathrm{Ca}^{2+}$ を能動輸送するイオンポンプ である. SERCAの阻害はカルシウムイオンの恒常性を 乱し，結果的に小胞体ストレスを誘導する。実際に，ヒ 卜子宮頸がん細胞をビセリングビアサイド類で処理した ところ, 細胞質内のカルシウムイオン濃度が上昇し, 小 胞体ストレスが誘導されることがわかった（図1B)。現 在，SERCAを標的とする医薬品は上市されていない が，強力な阻害剤であるタプシガルジン $\left(K_{\mathrm{i}} 0.1 \mathrm{nM}\right)$ のペプチド誘導体が前立腺がんの治療薬として第二相の 臨床試験に供されている ${ }^{(7)}$. そのほかのSERCA 阻害剤 としては, カビ毒シクロピアゾン酸や2,5-di-tert-butyl-1,4-benzohydroquinone (BHQ) がよく知られてい る。しかし, SERCAとの親和性はどちらの阻害剤も夕 プシガルジンの1万分の 1 程度にとどまっており（Ki $1 \mu \mathrm{M})$ ，ビセリングビアサイド類の強い親和性と阻害機 構に興味がもたれた。

これまでに，マクロリド系化合物がSERCA 阻害郕と して報告された例はなく，ビセリングビアサイド類の結 合様式はほかの阻害剤と大きく異なると考えられた。 そ こで筆者らは，速筋のカルシウムポンプである SERCA1aにビセリングビアサイド類が結合した複合体 を結晶化し，X線結晶解析により $3.2 \sim 3.5 \AA$ 分解能で結 合様式を明らかにした ${ }^{(6)}$. SERCA1aは分子量 $110 \mathrm{kDa}$ の膜タンパク質であり, 細胞質領域の 3 つのドメイン （A，Nおよび $\mathrm{P} ）$ と 10 本の膜貫通 $\alpha$-ヘリックス（M1〜 M10）から構成されている. 決定された結晶構造では, ビセリングビアサイド類は細胞質ドメインと膜貫通領域 の境界領域に結合し，その結合様式は既知の阻害剤とは 明膫に異なっていた（図1B)。結合サイトの一部はシク ロピアゾン酸やBHQのサイトとも重なるが，ビセリン グビアサイド類はこれら阻害剤に比べ, 約 1,000 倍も高 い親和性を示した。これは，ビセリングビアサイド類が 細胞質ドメインまで含めた広い範囲の残基と相互作用し ていることに起因すると考えられる。

ビセリングビアサイド類の結合様式において特に重要 なのは, 膜貫通へリックス $\mathrm{M} 3, \mathrm{M} 4$ および細胞質側 $\mathrm{P}$ ド メインの $\alpha$-ヘリックス $(\mathrm{P} 1)$ と，ビセリングビアサイ ド類の側鎖抒よび1,3-共役ジエン近傍との疎水的相互作 
A

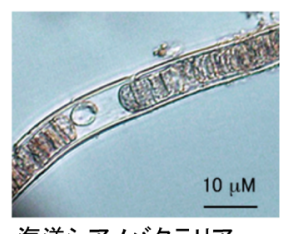

海洋シアハバクテリア

Lyngbya sp.

B

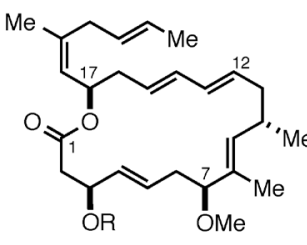

ビセリングビオライドB : R = H

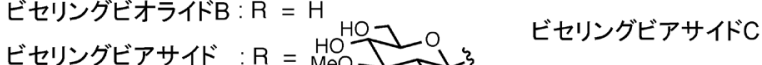

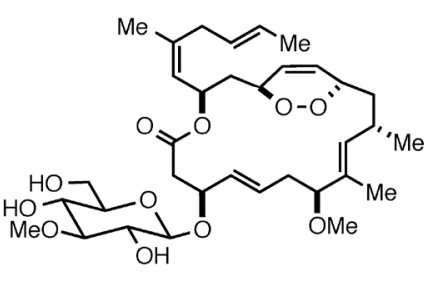

C

細胞膜

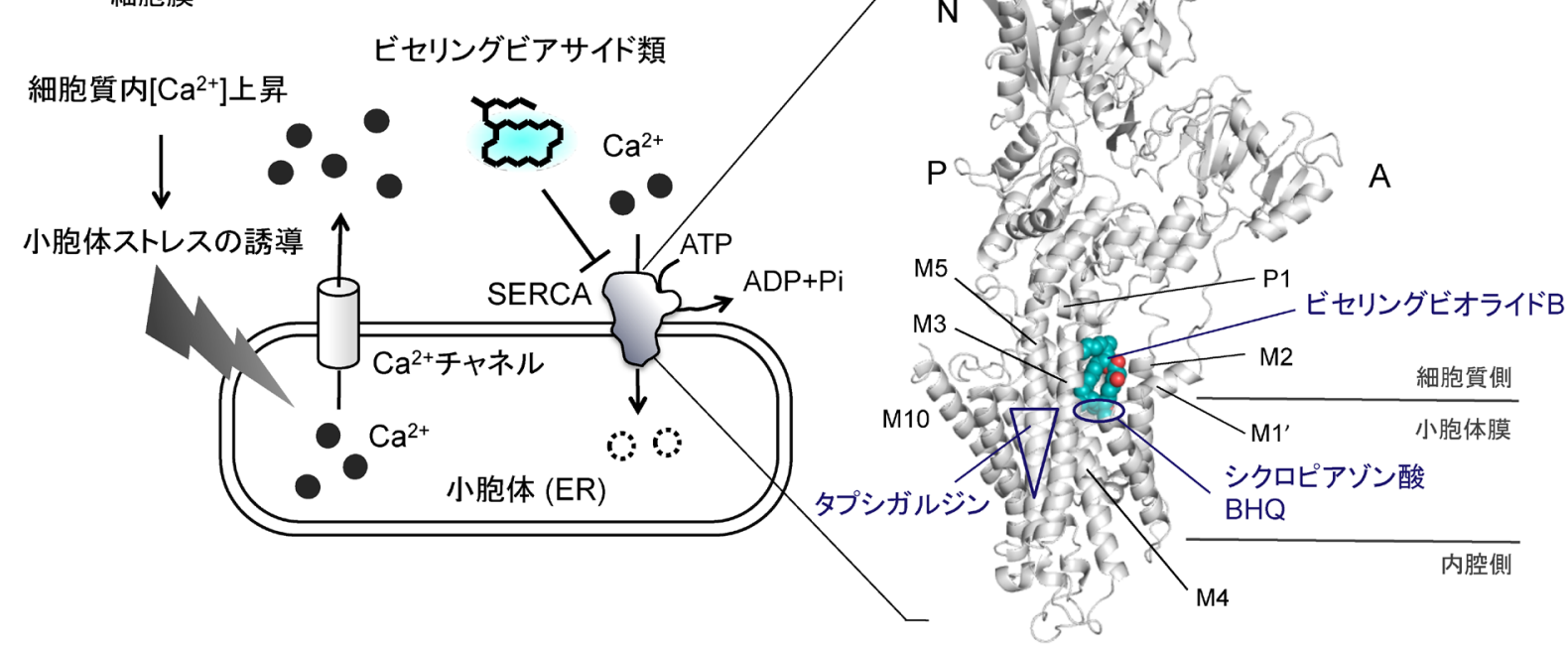

\section{図 1 -ビセリングビアサイド類の作用機序}

A. 海洋シアノバクテリアLyngbya sp. とビセリングビアサイド類の化学構造 B. ビセリングビアサイド類の作用メカニズム（左）およびカ ルシウムポンプービセリングビアサイド複合体の結晶構造（右）C. ビセリングビオライドBの結合様式.

用である (図 $1 \mathrm{C})$. 対照的に, マクロラクトン環の C2 〜 C6 周辺と膜貫通ヘリックス $\mathrm{M} 1$ およびM2の間には隙 間がある。したがって，C2〜C6周辺の官能基化やマク ロラクトン部の環拡大などにより親和性の向上が可能か もしれない. 海洋生物由来のマクロリドには, 分子内に 多くの $s p^{3}$ 炭素と酸素官能基をもつものも多数存在する が, ここでは疎水的かつ $s p^{2}$ 炭素を多く含む独自の化学 構造が高親和性結合の鍵を握っている.

ここで，構造活性相関に目を向けたい．ヒトがん細胞 に対しては，糖をもたないアグリコンは配糖体に比べ約 100 倍強い増殖抑制活性を示した。これに対して, SERCA1aに対するin vitroの阻害活性は, 配糖体とそ のアグリコンで同等であった。この違いは細胞膜に対す る透過性によると推察されるが, 興味深いことに, シア ノバクテリアからの収量は配糖体が最も多い。配糖体を アグリコンの不活性前駆体として利用しているのか, そ
れとも生体内での蓄積や排出のために糖を付加している のか, シアノバクテリア自身にとっての配糖体の役割は よくわかっていない. また, エンドペルオキシド構造を もつ類縁体は, 細胞増殖抑制活性・SERCA 阻害活性と もに著しく低かった。この結果は, 前述の1,3-共役ジエ ンが重要であるという結晶構造の知見からも納得でき る. 最近, 抗マラリア薬であるアルテミシニンが SERCAを含む 124 種ものタンパク質に結合することが 報告された ${ }^{(8)}$. ビセリングビアサイド類はSERCAに対 しin vitroで強力な阻害活性を示したが, 細胞内では SERCAのほかにも標的分子をもつのかもしれない. 実 際, 前述のJFCR39における細胞株間の比較では, ビセ リングビアサイド類の細胞増殖阻害活性がSERCAの遺 伝子発現量と相関しないという予備的知見も得られてい る.ビセリングビアサイド類の作用メカニズムを理解す るうえで, 今後, こうした複雑な生物活性や標的分子と 


\section{今日の話題}

の弱い相互作用にも着目していきたい.

本稿では，天然物ビセリングビアサイド類の作用機序 研究を紹介した。ビセリングビアサイド類の結合様式が 明らかになり，SERCAを標的とする薬剤に関して重要 な設計指針を得ることができた。創薬という視点から は, SERCA は正常細胞にも発現しており，組織特異性 をいかに与えるかが課題である。デリバリー技術と組み 合わせたことで抗がん剤のリードとなったタプシガルジ ンの例に見られるように，異分野とのシームレスな連携 がますます重要になると考えられる。ここで得られた結 晶構造が，今後の薬剤設計・合成・活性評価という正の サイクルを回すための起爆剤となることを期待したい.

1) G. M. Cragg \& D. J. Newman: Biochim. Biophys. Acta, 1830, 3670 (2013).

2) T. Teruya, H. Sasaki, K. Kitamura, T. Nakayama \& K. Suenaga: Org. Lett., 11, 2421 (2009).

3) M. Morita, O. Ohno, T. Teruya, T. Yamori, T. Inuzuka \& K. Suenaga: Tetrahedron, 68, 5984 (2012).

4) T. Yonezawa, N. Mase, H. Sasaki, T. Teruya, S. Hasegawa, B. Y. Cha, K. Yagasaki, K. Suenaga, K. Nagai \& J. T. Woo: J. Cell. Biochem., 113, 440 (2012).

5) T. Yamori, A. Matsunaga, S. Sato, K. Yamazaki, O. Nakanishi, H. Kohno, Y. Nakajima, H. Komatsu, Y. Andoh \& T. Tsuruo: Cancer Res., 59, 4042 (1999).

6) M. Morita, H. Ogawa, O. Ohno, T. Yamori, K. Suenaga \& C. Toyoshima: FEBS Lett., 589, 1406 (2015).

7) N. T. Doan, E. S. Paulsen, P. Sehgal, J. V. Møller, P. Nissen, S. R. Denmeade, J. T. Isaacs, C. A. Dionne \& S. B. Christensen: Steroids, 97, 2 (2015).

8) J. Wang, C. J. Zhang, W. N. Chia, C. C. Y. Loh, Z. Li, Y. M. Lee, Y. He, L. X. Yuan, T. K. Lim, M. Liu et al.: Nat. Commun., 6, 10111 (2015).

(森田真布*1,2, 小川治夫*1, 末永聖武*3, 豊島 近*1, $* 1$ 東京大学分子細胞生物学研究所, $* 2$ 工夕大学, $* 3$ 慶 應義塾大学)

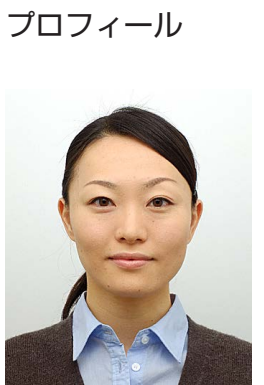

森田 真布 (Maho MORITA)

<略歴>2010年慶應義塾大学理工学部化 学科卒業 $/ 2013$ 年日本学術振興会特別研 究員 $/ 2015$ 年慶應義塾大学理工学研究科 所定単位取得退学 /同年東京大学分子細胞 生物学研究所博士研究員 / 2016 年米国工 夕大学創薬化学科博士研究員, 現在に至る <研究テーマと抱負 $>$ 天然物の構造と生物 活性発現機構 $<$ 趣味 $>$ 漂流物収集, 読書

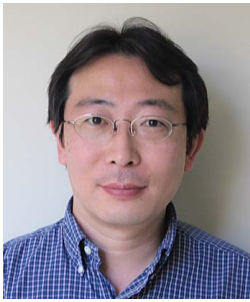

小川 治夫 (Haruo OGAWA)

<略歴>1992年東京工業大学理学部卒 業/1997年同大学生命理工学研究科単位 取得退学（1998年同大学生命理工学研究 科 博士 (理学)取得) / 1997年東京大学医 学系研究科助手 $/ 1999$ 年同大学分子細胞 生物学研究所助手 $/ 2002$ 年米国クリーブ ランドクリニックラーナー研究所博士研究 員 / 2004 年ネバダ州立大学生化学・分子 生物学学科リサーチアシスタントプロ フェッサー / 2007 年東京大学分子細胞生 物学研究所准教授, 現在に至る<研究テー マと抱負 $>$ 膜輸送体や膜受容体の機能・構 造相関 $<$ 趣味 $>$ 音楽鑑賞，フライフィッシ ング

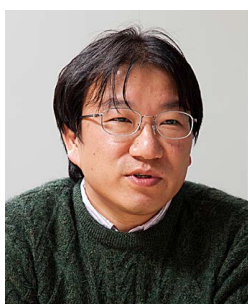

末永 聖武 (Kiyotake SUENAGA)

<略歴>1992年名古屋大学理学部化学科 卒業 $/ 1995$ 年同大学院理学研究科博士課 程中退/同年同大学理学部助手 / 2001 年 静岡県立大学薬学部助手 / 2003 年筑波大 学化学系講師 $/ 2006$ 年慶應義塾大学理工 学部化学科助教授 / 2007 年同准教授 / 2015年同教授, 現在に至る<研究テーマ と抱負 $>$ 天然物化学, 海洋シアノバクテリ ア由来の新規生物活性物質の探索, 合成, 生物活性とその存在意義について<趣味> クラッシック音楽鑑賞（特にオーケストラ と室内楽)

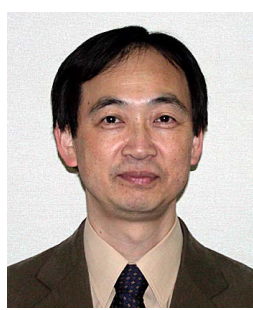

豊島 近 (Chikashi TOYOSHIMA)

<略歴>1978年東京大学理学部物理学科 卒業 / 1983 年同大学大学院理学系研究科 博士課程修了/ 1984 年同大学理学部助 手 / 1986年米国スタンフォード大学細胞 生物学教室博士研究員/1988年英国 MRC 分子生物学研究所研究員 / 1989 年理化学 研究所国際フロンティア研究員 / 1990年 東京工業大学理学部 (生命理工学部) 助教 授 / 1994 年東京大学分子細胞生物学研究 所教授 / 2008 年カリフォルニア大学バー クレー 校Hitchcock Professor（兼任）／ 2009年国立台湾大学Distinguished Research Chair Professor（兼任) / 2010年東 京大学分子細胞生物学研究所附属高難度蛋 白質立体構造解析センター長，現在に至る

Copyright (C) 2016 公益社団法人日本農芸化学会 DOI: 10.1271/kagakutoseibutsu.54.710 